\title{
Evaluation of the Fun FRIENDS program with a sample of Mexican children
}

Evaluación del Programa AMISTAD y Diversión en una muestra de niños mexicanos

\author{
Avaliação do programa Fun FRIENDS com uma amostra \\ de crianças mexicanas
}

\author{
Julia Gallegos-Guajardo ${ }^{1}$ \\ Norma A. Ruvalcalba-Romero² \\ Ania Chávez-Amavizca ${ }^{3}$ \\ Paula Barrett ${ }^{4}$
}

Recibido: 3 de enero de 2019

Aprobado: 13 de abril de 2020

Publicado: 20 de mayo de 2020

Cómo citar este artículo:

Gallegos-Guajardo, J., Ruvalcaba-Romero, N.A., Chavez-Amavizca, A. \& Barrett, P. (2020). Evaluation of the Fun FRIENDS program with a sample of Mexican children.

Pensando Psicología, 16(1), 1-21.

doi: https://doi.org/10.16925/2382-3984.2020.01.03

Artículo de investigación. https://doi.org/10.16925/2382-3984.2020.01.03

1 Universidad de Monterrey

ORCID: https://orcid.org/0000-0001-5678-2353

Correo electrónico: julia.gallegos@udem.edu

2 University of Guadalajara

ORCID: https://orcid.org/0000-0001-9209-8751

3 Universidad de Monterrey

ORCID: https://orcid.org/0000-0001-6450-9357

4 Edith Cowan University

ORCID: https://orcid.org/0000-0003-2824-4560 


\begin{abstract}
Introduction: Anxiety symptoms in young children can have negative consequences such as the deterioration of family and interpersonal functioning, and may lead to the development of an anxiety disorder; therefore, the importance of prevention.
\end{abstract}

Objective: The aim of this study was to evaluate the effectiveness of the Fun FRIENDS program in the reduction of children's anxiety symptoms and the promotion of emotional and behavioral competences as a protective factor in a sample of Mexican children.

Methodology: The participants included 49 children from the first grade at elementary school along with their teachers. The program was implemented by teachers as twelve consecutive one-week sessions conducted in the classroom. The outcome was measured with a pretest-posttest quasi-experimental design. Measures included the Preschool Anxiety Scale (PAS) for parents, Behavioral and Emotional Rating Scale (BERS-2) for parents and Strengths and Difficulties Questionnaire (SDQ), for parents and teachers.

Results: Findings showed a decrease in the subscale of separation anxiety of the PAS, an increase in the interpersonal, intrapersonal and affective strengths subscales of the BERS-2, and an increase in prosocial behavior as measured by the SDQ.

Conclusions: Results indicate promise for the effectiveness of the Fun FRIENDS program as an early intervention program based on the promotion of resilience for Mexican children.

Keywords: Anxiety, Children, Fun FRIENDS, Prevention, Resilence.

\title{
Resumen
}

Introducción: los síntomas de ansiedad en niños pequeños pueden tener consecuencias negativas como el deterioro del funcionamiento familiar e interpersonal, y puede llevar al desarrollo de un trastorno de ansiedad; por ello, es importante la prevención.

Objetivo: evaluar la efectividad del programa Fun FRIENDS en la reducción de los síntomas de la ansiedad de los niños y en la promoción de competencias emocionales y conductuales como un factor de protección en una muestra de niños mexicanos.

Metodología: los participantes incluyeron 49 niños de primer grado en una escuela primaria junto a sus maestros. El programa fue implementado por los maestros en sesiones semanales realizadas en el aula durante 12 semanas consecutivas. El resultado se midió con un diseño cuasiexperimental pretest postest. Las medidas incluyeron la Preeschool Anxiety Scale (PAS) para padres, la Behavioral and Emotional Rating Scale (BERS-2) para padres y la Strengths and Difficulties Questionnare (SDQ) para padres y maestros.

Resultados: los hallazgos muestran un decremento en la subescala de ansiedad por separación del PAS, un incremento en las subescalas interpersonales, intrapersonales y afectivas del BERS-2, y un incremento en el comportamiento prosocial de acuerdo con el SDQ.

Conclusiones: los resultados sugieren el programa Fun FRIENDS promete ser efectivo como un programa de intervención temprana basada en la resiliencia de los niños mexicanos.

Palabras clave: ansiedad, infancia, Fun FRIENDS, prevención, resiliencia.

\section{Resumo}

Introdução: os sintomas de ansiedade em crianças pequenas podem ter consequências negativas, como comprometimento do funcionamento familiar e interpessoal, e podem levar ao desenvolvimento de um transtorno de ansiedade; portanto, a prevenção é importante. 
Objetivo: avaliar a eficácia do programa Fun FRIENDS na redução dos sintomas de ansiedade em crianças e na promoção de competências emocionais e comportamentais como fator de proteção em uma amostra de crianças mexicanas.

Metodologia: Os participantes incluíram 49 alunos da primeira série de uma escola primária, juntamente com seus professores. 0 programa foi implementado pelos professores em sessões semanais realizadas em sala de aula durante 12 semanas consecutivas. 0 resultado foi medido com um desenho pós-teste de pré-teste quase experimental. As medidas incluíram a Escala de Ansiedade Pré-escolar (PAS) para os pais, a Escala de Avaliação Comportamental e Emocional (BERS-2) para os pais e o Questionário de Força e Dificuldades (SDQ) para pais e professores.

Resultados: os achados mostram uma diminuição na subescala de ansiedade de separação do PAS, um aumento nas subescalas interpessoal, intrapessoal e afetiva do BERS-2 e um aumento no comportamento pró-social de acordo com o SDQ.

Conclusões: os resultados sugerem que o programa Fun FRIENDS promete ser eficaz como um programa de intervenção precoce baseado na resiliência de crianças mexicanas.

Palavras-chave: ansiedade, infância, Fun FRIENDS, prevenção, resiliência.

\section{Introduction}

Mental health problems affect one out of five children and teenagers worldwide, with anxiety disorders ranking as the most common one of all (Kieling et al., 2011; Polanczyk, Salum, Sugaya, Caye, \& Rhode, 2015). Furthermore, the World Health Organization $(\mathrm{WHO}, 2017)$ estimates that $3.6 \%$ of the world population is affected by anxiety disorders. Similarly, within the Mexican population, anxiety disorders are also identified as one of the most common mental health issues (Benjet et al., 2009; Medina-Mora et al., 2009). The prevention and early intervention to treat the symptoms of anxiety is extremely important, as half of the cases have an onset in childhood or adolescence (Belfer, 2008; Costello, Egger, \& Angold, 2005). Anxiety symptoms in young children can appear in different forms, for example, children suffering from generalized anxiety disorders may worry excessively about a variety of things such as school grades and relationships with peers, while those with separation anxiety may experience excessive anxiety when being away from home or when separated from parents, sometimes refusing to go to school or bed alone. These symptoms can have short-term consequences, such as the deterioration of family and interpersonal functioning domains (Chang, Quan, \& Wood, 2012; Towe-Goodman, Franz, Copeland, Angold, \& Egger, 2014), as well as long-term consequences, such as the development of an anxiety disorder and an increased risk of substance abuse (Medina-Mora et al., 2009, Merikangas et al., 1998). 
The development of effective preventive strategies for early symptoms of anxiety is crucial. Considering that the severity level of an anxiety disorder correlates with the probability of receiving timely treatment and that most of the population that suffers from an anxiety disorder does not receive the appropriate treatment (Belfer, 2008, Medina-Mora et al., 2009), it is imperative to develop an effective preventive intervention for early symptoms of anxiety. Interventions during childhood have demonstrated that anxiety problems can be reduced in the long term, since individuals are more adaptable at this age and stage of life (Barrett, Cooper, \& Anthony, 2014; Dadds et al., 1999).

During the last decades, researchers have proposed a more strength-based model by paying attention to those individuals who did not develop mental health disorders despite experiencing extremely challenging situations in life. This model served as the foundation for measuring 'resilience'. "Resilience refers to the adaptation and survival of a system after perturbation, often referring to the process of restoring functional equilibrium, and sometimes referring to the process of successful transformation to a stable new functional state. As a living system, a human individual could be described as resilient when showing a pattern of adaptation or recovery in the context of potentially destabilizing threats" (Masten, 2014, p.9). In psychology, resilience refers to an individual's ability to use effective coping strategies to face difficulties and overcome adversity (Masten, Best, \& Garmezy, 1990; Ruttledge et al., 2016), which in turn increases emotional resilience and can help to prevent the progression of mental health problems.

The development of resilience and emotional and behavioral competences are of great importance, especially for preventing the appearance of early symptoms of anxiety.Students who are socially and emotionally well adapted often report fewer symptoms of anxiety, behavioral inhibition, and shyness (Barrett, Fisak, \& Cooper, 2015; Pahl \& Barrett, 2010). The link between emotional and behavioral competences and anxiety has been explored in a meta-analytic review conducted with 185 studies (Mathews, Koehn, Abtahi, \& Kerns, 2016) reporting that anxious children and adolescents were less effective at expressing and understanding emotions, less aware of and less accepting of their own emotions, and report less emotional self-efficacy. This meta-analytic review also found that anxious youth were more likely to use avoidant and maladaptive cognitive coping.

Resilience-building programs have also manifested benefits beyond anxiety prevention, such as improvement of academic performance and self-efficacy (Anthony, Alter \& Jenson, 2009). In Mexico, few studies that address resilience-building have been conducted. One of them, conducted by Gallegos, Ruvalcaba, Garza and 
Villegas (2013), aimed to evaluate the social validity of the Spanish version of FRIENDS for Life Program, a cognitive-behavioral intervention focused on increasing social and emotional competence in children.

The FRIENDS programs are evidence-based resilience programs conducted in a school setting that focus on prevention of anxiety symptoms by developing social-emotional competencies and resilience (Barrett et al., 2014; Barrett et al., 2015). The theoretical model for prevention and early intervention of anxiety addresses four processes: attachment (emotions), physiological (body), cognitive (mind) and learning (behavior), which are seen to interact in the development and mantainance of anxiety. The skills and techiniques taught in the program are associated with these four areas, acknowledging the interaction between them and the individual differences that may exist in the influence of each process depending on the individual and his or her context. The school setting has been shown to be an optimal environment for the development of social-emotional skills taught by the FRIENDS programs (Barrett, et al., 2014). The FRIENDS programs are based on cognitive behavioral therapy, which has been proven to be highly effective in the treatment of a range of anxiety disorders (Butler, Chapman, Forman \& Beck, 2006).

The Fun FRIENDS program focused on increasing protective factors in preschool-aged children (four to seven years old). Positive results have been reported on the effectiveness of the Fun FRIENDS program. Pahl and Barrett (2010) conducted a study to evaluate the effectiveness of the Fun FRIENDS program in a sample of 263 preschool children. In this study, the teachers' self-reports revealed statistically significant decreases in inhibited behavior and increases in social-emotional competence by the end of the intervention. Likewise, based on the parents' self-reports, there were statistically significant decreases in anxiety symptoms, decreases in inhibited behavior, and increases in social-emotional competencies reported one year after participation in the program.

Another study, conducted by Anticich, Barrett, Silverman, Lacherez and Gillies (2013), evaluated the effectiveness of the Fun FRIENDS program as implemented by teachers to a sample of 488 preschool students, between four and seven years of age, in Brisbane, Australia. The results revealed a positive impact in the intervention group, specifically demonstrating statistically significant decreases of inhibited behavior and behavior problems, increases in socio-emotional competence, decreases in parental stress, and improvement in parent-child interactions. These results were found once again at the time of the 12-month follow up.

Likewise, in a clinical context, positive results have also been reported. Barrett, Fisak and Cooper (2015) implemented the Fun FRIENDS program in a group format 
to 31 children diagnosed with an anxiety disorder, reporting statistically significant decreases in anxiety symptoms and shyness, as well as improvements in resilience, after the intervention and at the time of the 12-month follow up (Barrett et al., 2015).

To date, only one study has examined the effectiveness of the Fun FRIENDS program in Mexico. Zertuche (2012) conducted a pilot study with a group of eight preschoolers from a city in northern Mexico with the purpose of evaluating the effectiveness of the program in the development of emotional resilience for this group. The results revealed statistically significant and positive changes at post intervention, finding decreases in anxiety symptoms and inhibited behavior, as well increases in socio-emotional competence and happiness. Similarly, relatively few studies dealing with resilience in Mexican samples have been conducted (i.e., Gallegos-Guajardo, Ruvalcaba-Romero, Garza-Támez, \& Villegas-Guinea, 2013; Gallegos et al., 2013).

\section{Objectives and Hypothesis}

The purpose of this study was to evaluate the effectiveness of the Spanish version of the Fun FRIENDS program as a universal, preventive, school-based intervention. The research questions were as follows: 1) What is the effect of the Fun FRIENDS program on students' symptoms of anxiety and social and emotional competence as rated by their parents?, 2) What is the effect of the Fun FRIENDS program on students' difficulties and prosocial behavior, as rated by their parents?, and 3)What is the effect of the Fun FRIENDS program on students' difficulties and prosocial behavior as rated by their classroom teachers? It was hypothesized that after receiving the intervention: 1) parents will report a decrease in the anxiety symptoms of their children as well as an increase in their social and emotional competence, 2) parents will report a decrease in their children's difficulties as well as an increase in their prosocial behavior, and 3) teachers will report a decrease in their children's difficulties as well as an increase in their prosocial behavior

\section{Method}

\section{Participants}

The participants of this study included 49 boys and girls (51\% boys), ages 6 to 7 years old $(M=6.55$ years old, $S D=.50)$, that were first grade students of a public elementary school of low socio-economic level in Monterrey, Mexico. The parents of 
each student, as well as the two classroom teachers, completed self-report measures about the participants. To ensure confidentiality, no identifying information was collected. Participation was completely voluntary and there was no compensation. Approval for this study was obtained from each of the schools, and all procedures were in accordance with the ethical standards of the 1964 Helsinki Declaration and its later amendments.

\section{Measures}

In addition to a demographics questionnaire, the following measures were completed: The Preschool Anxiety Scale (PAS). The PAS (Spence, Rapee, McDonald, \& Ingram, 2001) is a self-report measurement scale answered by the parents aimed to evaluate the symptoms of anxiety in the child. The model is based on the relationship of how children's thoughts and perceptions can lead to emotions and behaviors; specifically, how distorted perceptions can lead to unhealthy emotions and behaviors such as avoidance and reassurance; including as well the components of the tripartite model proposed by Watson and Clark (1991). The PAS consists of 34 items, each with five Likert type response options ( $0=$ Never to $4=$ Most of the time), generating a total score and a specific score for four anxiety disorders: Generalized anxiety (i.e.,"Has difficulties stopping him/herself from worrying"), Obsessivecompulsive disorder (i.e., "Washes his/her hands over and over many times each day"), Fear of physical injuries (i.e. "Is scared of heights (high places)"), and Separation anxiety (i.e., "Is reluctant to go to sleep without you or to sleep away from home"). The PAS, in its original version, has shown a strong internal consistency, both in the total scale and its subscales (Edwards, Rapee, Kennedy \& Spence, 2010). In regards to the PAS, Spence et al. (2001) reported an internal consistency of $a=.95$; for Generalized anxiety, $a=.90$; for Obsessive-compulsive disorder, $a=.78$; for Physical injury fears, $a$ $=.78$; and for Separation anxiety, $a=.94$. For the present study, a back-to-back translation was conducted by two university professors from the School of Psychology in Mexico, and items were revised to ensure accuracy and representativeness. The internal consistency of the PAS in Spanish for the current sample included $a=.86$ for the total score while the rest of the subscales reported adequate internal consistencies between .71 and .77 , with the exception of the subscales of OCD $(a=.40)$ and Physical injury fears $(a=.62)$.

The Behavioral and Emotional Rating Scale- Second Edition (BERS-2) (Epstein, 2010). The BERS-2 Parent Report is a self-report measurement scale (answered by both parents) designed to assess the emotional and behavioral strengths of children in 
five areas: Interpersonal strengths (i.e., "If I hurt or upset others I tell them I am sorry"), Family participation (i.e., "I get along well with my family"), Intrapersonal strengths (i.e., "I know what I do well"), School performance (i.e., "I pay attention in class"), and Affective strengths (i.e., "I care about how others feel") (Epstein, Harniss, Pearson, \& Ryser, 1999; Epstein \& Sharman, 1998). This questionnaire consists of 52 items with four Likert type response options ( $0=$ Does not describe the child to $3=$ Describes the child exactly). In its original version, the scale has shown strong internal consistency for the total score and its five subscales, ranging from $a=.83$ to $a=.98$ (Epstein et al., 1999). The present study utilized the Spanish version of The BERS-2 (Epstein, 2010), which has shown strong internal consistency for the total score and its five subscales, ranging from a = .84 to $a=.91$ (Sharkey, Sukkyung, Morrison \& Griffiths, 2009). The internal consistencies reported from the current sample included: Interpersonal strengths $a=.73$, Family participation $a=.74$, Intrapersonal strengths $a=.80$, School performance $a=.88$, and Affective strengths $a=.69$.

Strengths and Difficulties Questionnaire (SDQ). The Spanish version of the SDQ (Goodman, 1997) was completed by both parents and teachers. The SDQ is a self-report measure designed to assess psychological adjustment in children between 3 and 16 years of age in five areas: Emotional symptoms, Behavioral problems, Hyperactivity, Problems with peers, and Pro-social behavior. It consists of 25 items with three Likert type response options ( $0=$ Not true to $2=$ Absolutely true). In its original version, the SDQ has shown satisfactory internal reliability $(a=.73)$ (Goodman, 2001). For the current sample, the internal consistency was $a=.80$ for the parent version and $a=.76$ for the teacher version.

\section{Procedure}

Parents were informed by the school that their children were invited to participate in the program. The invitation was open and optional; those who agreed were asked to complete a survey about their children and their behavior, and their children received the program as part of their regular classroom activities. This survey was completed before the intervention (pretest) and immediately after the intervention (posttest). Parents were also invited to two optional 90-minute informational sessions that explained the content of the program. In these sessions, parents gained an understanding of the concepts, strategies, and skills that their children were taught in the program so they could then assist and support them at home. Parent sessions included information on anxiety, developmental issues, positive parenting, and family resilience-building strategies. 
The facilitators of the program were two classroom teachers who completed a nine-hour training session to become facilitators of the program. The two teachers implemented the Fun FRIENDS program in their classrooms. The program took place over a period of three months, in 12 consecutive sessions, each with conducted once a week with a duration of 60 to 75 minutes. An ANOVA was conducted to compare the pretests and posttests' results between the two classrooms, and no statistically significant differences were observed between the two groups.

\section{Intervention}

The Fun FRIENDS program was implemented in its Spanish version, Amistad y Diversión (Barrett, 2011). This program teaches children cognitive-behavioral strategies to develop social and emotional strength, build resilience, and decrease anxiety symptoms. It uses activities based on play and experiential learning (see Table 1).

Table 1. Outline of the content of the Fun FRIENDS Program.

\begin{tabular}{|c|c|}
\hline Session & Content - Main Learning Objectives \\
\hline \multirow{4}{*}{ Session 1} & - Development of a sense of identity and introduction to the group. \\
\hline & - Introduction of the concept of "being brave", promoting social skills. \\
\hline & - Acceptance of differences. \\
\hline & - Example of activity: Drawing a picture of your family \\
\hline \multirow{3}{*}{ Session 2} & F: Feelings \\
\hline & $\begin{array}{l}\text { - Affective education and identification of several emotions, including physiological activation } \\
\text { associated with emotions. }\end{array}$ \\
\hline & - Example of activity: Coloring the koalas' feelings and identifying feelings for different situations. \\
\hline \multirow{5}{*}{ Session 3} & F: Feelings (continued) \\
\hline & - How to cope with helpful feelings and coping behaviors. \\
\hline & - Awareness of the link between feelings and behaviors. \\
\hline & - Strategies to help others when they experience certain feelings, development of empathy. \\
\hline & $\begin{array}{l}\text { - Example of activity: Looking at a scenario and brainstorming ideas to help a koala that is not } \\
\text { playing with anyone during recess. }\end{array}$ \\
\hline \multirow{4}{*}{ Session 4} & R: Remember to relax \\
\hline & - Identification of physiological activation (body signs) related to anxiety. \\
\hline & $\begin{array}{l}\text { - Relaxation strategies that include diaphragmatic breathing (shake breathing), progressive } \\
\text { muscle relaxation, and visualization. }\end{array}$ \\
\hline & $\begin{array}{l}\text { - Example of activity: Practicing diaphragmatic breathing as a group with fun exercises called } \\
\text { bubble breathing. }\end{array}$ \\
\hline
\end{tabular}


(viene)

\begin{tabular}{|c|c|}
\hline Session & Content - Main Learning Objectives \\
\hline \multirow{5}{*}{ Session 5} & I: I can try my best! \\
\hline & - Introduction to the cognitive components of the program. \\
\hline & - Children are taught to become aware and pay attention to their thoughts or self-talk. \\
\hline & $\begin{array}{l}\text { - Self-talk is explained in terms of red (not useful thoughts) and green (useful thoughts), using the } \\
\text { analogy of the traffic light. }\end{array}$ \\
\hline & $\begin{array}{l}\text { - Example of activity: Coloring different scenarios with red, green and yellow, depending on the } \\
\text { specific self-talk of the characters. }\end{array}$ \\
\hline \multirow{4}{*}{ Session 6} & I: I can try my best (continued) \\
\hline & $\begin{array}{l}\text { - Introduction to the challenge of unhelpful red thoughts and generation of useful green thou- } \\
\text { ghts as alternatives. }\end{array}$ \\
\hline & - Use of green thoughts to help achieve goals. \\
\hline & $\begin{array}{l}\text { - Example of activity: Identifying with pictures different drawings as the outcome of the type of } \\
\text { self-talk of the character. }\end{array}$ \\
\hline \multirow{3}{*}{ Session 7} & E: Encourage \\
\hline & $\begin{array}{l}\text { - Trying new things by dividing tasks into small steps and using green thoughts to help achieve } \\
\text { goals. }\end{array}$ \\
\hline & - Example of activity: Creating a step-plan for a specific goal. \\
\hline \multirow{4}{*}{ Session 8} & N: Nurture \\
\hline & $\begin{array}{l}\text { - Introduction to kindness and altruistic behaviors to nurture ourselves and our relationships: be } \\
\text { friendly and make friends. }\end{array}$ \\
\hline & - Being a good friend: smile, share, help, and listen. \\
\hline & $\begin{array}{l}\text { - Example of activity: Providing different scenarios through pictures to discuss different ways to } \\
\text { help and be a good friend. }\end{array}$ \\
\hline \multirow{3}{*}{ Session 9} & N: Nurture (Continued) \\
\hline & - Interpersonal rewards: how to reward ourselves when we gave our best effort. \\
\hline & $\begin{array}{l}\text { - Example of activity: Creating a list of intrapersonal rewards that are relevant for each child } \\
\text { individually. }\end{array}$ \\
\hline \multirow{3}{*}{ Session 10} & N: Nurture (Continued) \\
\hline & - Role models and their influence on the formation of children's identity. \\
\hline & - Example of activity: Identifying and drawing role models. \\
\hline \multirow{3}{*}{ Session 11} & D: Don't forget to be brave \\
\hline & - Support teams in each area: family, friends, and teachers. \\
\hline & - Example of activity: Identifying and drawing social support groups. \\
\hline \multirow{3}{*}{ Session 12} & S: Stay Smiling \\
\hline & - Review of the learned strategies and celebration. \\
\hline & - Example of activity: Relaxation games and discussion of the different strategies learned. \\
\hline
\end{tabular}

Source: Own elaboration 


\section{Results}

\section{Anxiety}

A series of repeated-measures t-tests were conducted to assess changes in anxiety symptoms from pre to post-intervention (see Table 2).

Table 2. Results of the Preschool Anxiety Scale (PAS)

\begin{tabular}{|c|c|c|c|c|c|c|c|c|c|}
\hline \multirow{2}{*}{ Dependent Variable } & \multicolumn{3}{|c|}{ Pre-intervention } & \multicolumn{3}{|c|}{ Post-intervention } & \multirow{2}{*}{$t$} & \multirow{2}{*}{$p$} & \multirow{2}{*}{ Cohen's d } \\
\hline & $M$ & $S D$ & $n$ & $M$ & $S D$ & $n$ & & & \\
\hline PAS total & 20.40 & 11.44 & 40 & 19.70 & 12.73 & 40 & 0.48 & 0.314 & --- \\
\hline General Anxiety & .61 & .50 & 44 & .61 & .57 & 44 & 0.00 & 1.00 & -- \\
\hline $\begin{array}{l}\text { Obsessive Compulsive } \\
\text { Disorder }\end{array}$ & .39 & .38 & 46 & .37 & .47 & 46 & 0.39 & 0.347 & --- \\
\hline Fear of Physical Injuries & .87 & .58 & 44 & .92 & .93 & 44 & -0.59 & 0.277 & -- \\
\hline Separation Anxiety & .95 & .82 & 46 & .66 & .65 & 46 & 3.25 & 0.002 & .391 \\
\hline
\end{tabular}

Source: Own elaboration

\section{Emotional and Behavioral Strengths}

A series of repeated measures t-tests were conducted to measure potential changes in emotional and behavioral strengths from pre to post-intervention, as measured by the BERS-2 (see Table 3).

Table 3. Results of the Behavioral and Emotional Ratings Scale (BERS)

\begin{tabular}{|c|c|c|c|c|c|c|c|c|c|}
\hline \multirow{2}{*}{ Dependent Variable } & \multicolumn{3}{|c|}{ Pre-intervention } & \multicolumn{3}{|c|}{ Post-intervention } & \multirow{2}{*}{$t$} & \multirow{2}{*}{$p$} & \multirow{2}{*}{ Cohen'sd } \\
\hline & $M$ & $D E$ & $n$ & $M$ & $D E$ & $n$ & & & \\
\hline BERS total & 130.96 & 18.19 & 32 & 132.18 & 16.89 & 32 & 0.572 & 0.285 & --- \\
\hline Interpersonal strengths & 35.58 & 7.02 & 43 & 38.60 & 7.52 & 43 & -3.54 & 0.000 & .415 \\
\hline Family participation & 26.43 & 2.99 & 39 & 26.46 & 2.77 & 39 & -0.06 & 0.472 & --- \\
\hline Intrapersonal strengths & 27.61 & 3.93 & 44 & 28.66 & 3.92 & 44 & -2.38 & 0.010 & .267 \\
\hline School performance & 21.61 & 4.59 & 44 & 21.75 & 4.50 & 44 & -0.32 & 0.372 & --- \\
\hline Affective strengths & 16.26 & 1.82 & 45 & 18.91 & 2.58 & 45 & -7.78 & 0.000 & 1.18 \\
\hline
\end{tabular}

Source: Own elaboration 


\section{Psychological Adjustment}

A repeated-measures t-test was conducted to assess changes of indicators of psychological adjustment, as measured by the parent and teacher-report SDQ scores, from pre to post-intervention (see Tables 4 and 5).

Table 4. Strengths and Difficulties Questionnaire (SDQ) Results Teachers Version

\begin{tabular}{|c|c|c|c|c|c|c|c|}
\hline & \multicolumn{2}{|c|}{ Pre intervention } & \multicolumn{2}{|c|}{ Post intervention } & \multirow{2}{*}{$\boldsymbol{t}$} & \multirow{2}{*}{$p$} & \multirow{2}{*}{ Cohen'so } \\
\hline & $M$ & $S D$ & $M$ & $S D$ & & & \\
\hline Conduct problems & 0.36 & 0.46 & 0.39 & 0.45 & -0.71 & 0.48 & --- \\
\hline Emotional symptoms & 0.42 & 0.50 & 0.43 & 0.51 & -0.23 & 0.82 & -- \\
\hline Hyperactivity/inattention & 0.85 & 0.69 & 0.80 & 0.68 & 0.80 & 0.43 & --- \\
\hline Peer relationship problems & 0.38 & 0.41 & 0.37 & 0.40 & 0.27 & 0.78 & --- \\
\hline Prosocial behavior & 0.94 & 0.46 & 1.06 & 0.50 & -2.63 & 0.01 & .249 \\
\hline
\end{tabular}

Source: Own elaboration

Table 5. Strengths and Difficulties Questionnaire (SDQ) Results Parents Version

\begin{tabular}{lcccccc}
\hline & \multicolumn{2}{c}{ Pre intervention } & \multicolumn{2}{c}{ Post intervention } & \multirow{2}{*}{$\boldsymbol{t}$} & $\boldsymbol{p}$ \\
\cline { 2 - 6 } & $\boldsymbol{M}$ & $\boldsymbol{S D}$ & $\boldsymbol{M}$ & $\boldsymbol{S D}$ & & \\
\hline Conduct problems & 0.42 & 0.36 & 0.34 & 0.30 & 1.21 & 0.23 \\
\hline Emotional symptoms & 0.36 & 0.37 & 0.29 & 0.32 & 1.63 & 0.11 \\
\hline Hyperactivity/inattention & 0.86 & 0.55 & 0.84 & 0.58 & 0.00 & 1.00 \\
\hline Peer relationship problems & 0.29 & 0.31 & 0.31 & 0.36 & -0.68 & 0.50 \\
\hline Prosocial behavior & 1.69 & 0.30 & 1.76 & 0.28 & -0.63 & 0.53 \\
\hline
\end{tabular}

Source: Own elaboration

\section{Discussion}

The purpose of this study was to evaluate the effectiveness of the Fun FRIENDS program in the reduction of symptoms of anxiety in children and the promotion of emotional and behavioral competences in Mexican children. The results obtained showed statistically significant decreases in symptoms of separation anxiety evaluated with the PAS, increases in affective strengths, intrapersonal strengths, and interpersonal 
strengths evaluated with the BERS-2, and increases in pro-social behavior evaluated with the SDQ. Effect sizes ranged from a $d=1.18$ to $d=.415$. Therefore, as all of them were below .50 they are considered effect sizes of small magnitude. The magnitude of the effect sizes reported in this study were consistent with those reported in other studies evaluating prevention programs (Fisak, Richard, \& Mann, 2011).

In relation to anxiety symptoms, only statistically significant changes were observed in for separation anxiety. This partially confirms the present hypothesis, and partially agrees with the results found in previous studies conducted with community (Stopa et al., 2011; Zertuche, 2012) and clinical samples (Barrett et al., 2015) which reported statistically significant decreases in overall anxiety symptoms at post-intervention. Possible reasons for this could be related to the fact that the sample was non-clinical and low levels of anxiety are typically expected in pre-intervention, which may explain why there was not a significant change in anxiety levels after the intervention. These results differ from other studies conducted in community samples, where statistically significant decreases on anxiety levels have been reported (i.e., Rogers \& Dunsmuir, 2013; Stallard et al., 2014).

Finding significant differences in separation anxiety was a promising finding, as separation anxiety is one of the most common types of anxiety disorders experienced by young children (Beesdo, Knappe, Pine, 2009; (Medina-Mora et al., 2009). Given the age range of the current sample, the positive and significant effect on this subscale of this program is expected. Additionally, the fact that this program occurred in a school setting, an environment, which fosters fear, and anxiety responses related to the separation of the mother or caregiver, could have influenced the results. According to Figueroa, Soutullo, Ono and Saito (2016), the symptoms of separation anxiety appear more frequently in situations of change (i.e. during the transition from preschool to primary school), which was the specific situation experienced by the participants from this study. The current findings suggest the importance of training teachers and parents to support students with strategies to effectively cope with situations in which they may experience fear and anxiety. Furthermore, these findings emphasize the significance of teaching children social and emotional competencies to promote their resilience, in an effort to contribute to the prevention of anxiety and the wellbeing of children.

The non-significant findings on the difficulties subscales in the SDQ could also be explained by the floor or basement effect, as the present study utilized a universal intervention in a community sample of young children who were not expected to present high levels of emotional and inattentive symptoms nor conduct and peer problems. This is similar to what has been reported in other intervention studies 
implemented in community settings, which did not observe changes in symptoms of anxiety and depression after receiving the intervention (Anticich et al., 2013,; Stallard et al., 2014; Tomyn et al., 2016). On the contrary, changes in anxiety and depressive symptoms were observed in an intervention study conducted with a clinical sample after the participants received the program (Barrett et al., 2015). It is also important to note that in some studies which evaluated the program as a universal intervention, changes in the anxiety symptoms of the participants were observed only at the time of the 6 or 12-month follow up (Balle \& Tortella-Feliu, 2010; Essau et al., 2012; Pahl \& Barrett, 2010; Stallard et al., 2014), which could be due to the fact that these changes depend on the rate or frequency of which the acquired skills are applied.

In relation to emotional and behavioral competences, as evaluated by the BERS-2, the results of the present study showed statistically significant increases in affective strengths, intrapersonal strengths, and interpersonal strengths after the intervention, which partially corresponds to the hypothesis proposed in the present study and the results found in previous studies (Anticich et al., 2013; Pahl \& Barrett 2010; Zertuche, 2012). The absence of changes in the subscales of family strengths and school performance suggests that these are not yet observable in the post-intervention. A possible reason may be that the program did not directly target family interpersonal relationships and did not include content related to school performance. It may be that these two areas could benefit indirectly in the long run (Franco et al., 2017; Ojeda et al., 2013; Oswald et al., 2018).

Socio-emotional development may precede academic performance, and, as documented in previous research, the benefits may be observed for up to one year after the intervention (Balle \& Tortella-Feliu, 2010; Essau et al., 2012; Pahl \& Barrett, 2010; Stallard et al., 2014). Therefore, further research that explores this relationship and the long-term effect of the program on these variables in highly encouraged. As reported by Tomyn, et al. (2016), increasing students' resilience contributes to a process of positive long-term change, even when no immediate decreases in anxiety are observed. Likewise, greater involvement on the parents' behalf should be emphasized to guide the emotional and social learning of the children in order for the learned skills to be generalized to multiple contexts.

Finally, in relation to the difficulties and prosocial behavior evaluated by the SDQ, significant changes were only observed for the subscale of prosocial behavior answered by teachers, which partially supports the hypothesis of the study and partially agrees with results reported by Barrett, Fisak and Cooper (2015). One possible explanation for the fact that only the teachers, but not the parents, observed a statistically significant increase in the prosocial behavior of the children could be that the 
degree of parent involvement included in the program is not sufficient (Barrett, 2007a; 2007b). Another plausible explanation is that the school environment provides more opportunities to engage in prosocial behavior than at home. Although, as Higgins and O'Sullivan (2015) posed, more research is needed to uncover the extent of the impact that parent sessions have on the outcomes, the results of this study suggest that including more direct activities that could foster the transfer of knowledge and skills from the school to the home environment may be beneficial for long-term and sustainable changes.

In general, the results of this study highlight the importance of providing students with programs that promote social and emotional skills and resilience from an early age. Children that received interventions such as Fun FRIENDS have shown to develop strengths that could be utilized to prevent and early intervene for children's anxiety symptoms (Tomyn et al., 2016; Pahl \& Barrett, 2010; Zertuche, 2012).

\section{Limitations and implications for future research}

As a study conducting exploratory research, the results should be interpreted while taking into account its limitations. Some of the limitations of the study that should be considered include the lack of a control group and / or active comparison group using an analogous program of prevention of anxiety symptoms and promotion of social and emotional competencies in children, as well as the lack of measures to evaluate children's cognition and resilience. The fact that parents and teachers were the informants of this study and not the children themselves is one of the main limitations, as results are based on parents' and teachers' perceptions. Therefore, the interpretation of the changes in the behavior of the children is subjective, as a behavior is best measure when multiple informants are included as well as direct observation and qualitative interviews. The current study also lacked of a longitudinal follow-up at 6 or 12 months after the intervention was completed, a measure of intervention fidelity, and the absence of documentation tracking the attendance of parents to the two information sessions that were offered. Lastly, the low reliability indices yielded by some of the subscales in the current sample should be taken into account when interpreting the findings set forward in this study. It is recommended that future research target these limitations as much as possible and consider a mixed method design, as qualitative data could have greatly benefited the present study. In addition, further studies could shed light by also exploring variables that could be possible 
mediators of intervention effects, and evaluating the effects of an intervention at different leves of prevention such as universal prevention, for all children in the classroom, and selective prevention, for those children identified with anxiety symptoms.

\section{Conclusion}

This study contributes to the literature as it the second study thus far to have evaluated the effectiveness of the Fun FRIENDS program with a sample of Mexican children. It contributes to this field of study by also reporting the program's effects with measures of positive indicators of mental health (Anticich et al., 2013, Barrett et al., 2015, Pahl \& Barrett, 2010, Zertuche, 2012). Results demonstrated that the implementation of the Fun FRIENDS program was effective by significantly decreasing symptoms of separation anxiety, given that children experience anxiety at moments of separation from attachment figures in different context situations such as school settings. The results also reported an increase in the students' prosocial behavior as reported by the teachers, who received training and implemented the program in their own classrooms. Finally, a significant increase was also reported in the students' affective, intrapersonal, and interpersonal strengths as reported by parents. No significant differences were found for family strengths and school performance. The effect sizes reported were considered of small magnitude and consistent with those reported by similar studies that evaluate prevention programs for mental health. Further research is suggested to continue evaluating the impact of this program with different measures and research designs, including a larger sample size from different regions of the country and socioeconomic levels.

\section{References}

Anticich, S., Barrett, P., Silverman, W., Lacherez, P. \& Gillies, R. (2013). The Prevention of Childhood Anxiety and Promotion of Resilience among Preschool-Aged Children: A Universal School-Based Trial. Advances in School Mental Health Promotion, 6(2), 93-121. https://doi. org/10.1080/1754730X.2013.784616

Anthony, E., Alter, C. \& Jenson, J. (2009). Development of a Risk and Resilience-Based Out-OfSchool Time Program for Children and Youths. Social Work, 54(1), 45-55. 
Balle, M. \& Tortella-Feliu, M. (2010). Efficacy of a Brief School-Based Program for Selective Prevention of Childhood Anxiety. Anxiety Stress Coping, 23(1),71-85. https://doi.org/10.1080/ 10615800802590652

Barrett, P. M. (2007a). Fun Friends. The Teaching and Training Manual for Group Leaders. Brisbane: Fun Friends Publishing.

Barrett, P. M. (2007b). Fun Friends. Family Learning Adventure: Resilience Building Activities for 4-, 5-, and 6-Year-Old Children. Brisbane: Fun Friends Publishing.

Barrett, P., Cooper, M. \& Gallegos, J. (2014). Using the FRIENDS Programs to Promote Resilience in Cross-Cultural Populations. In Goldstein, S. (Ed), Resilience Interventions for Youth in Diverse Populations (pp. 85-108). New York: Springer.

Barrett, P., Cooper, M. \& Anthony, T. (2014). When Time is of the Essence: A Rationale For "Earlier" Early Intervention. Journal of Psychological Abnormalities in Children, 3(4), 1-9. https://doi. org/10.4172/2329-9525.1000133

Barrett, P., Fisak, B. \& Cooper, M. (2015). The Treatment of Anxiety in Young Children: Results of an Open Trial of the Fun FRIENDS Program. Behavior Change, 32(4), 231-242.

Belfer, M. (2008). Child and Adolescent Mental Disorders: The Magnitude of the Problem Across the Globe. The Journal of Child Psychology and Psychiatry, 49(3), 226-236.

Benjet, C., Borges, G., Medina-Mora, M., Méndez, E., Fleiz, C., Rojas, E. \& Cruz, C. (2009). Diferencias de sexo en la prevalencia y severidad de trastornos psiquiátricos en adolescentes de la Ciudad de México. Salud Mental, 32(2), 155-163.

Beesdo, K., Knappe, S. \& Pine, D. (2009). Anxiety and Anxiety Disorders in Children and Adolescents: Developmental Issues and Implications for DSM-V. The Psychiatric Clinics of North America, 32(3) 483-524. https://doi.org/10.1016/j.psc.2009.06.002

Butler, A., Chapman, J., Forman, E. \& Beck, A. (2006). The Empirical Status of Cognitive-Behavioral Therapy: A Review of Meta-Analyses. Clinical Psychology Review, 26(1), 17-31.

Chang, Y., Quan, J. \& Wood, J. (2012). Effects of Anxiety Disorder Severity on Social Functioning in Children with Autism Spectrum Disorders. Journal of Developmental and Physical Disabilities, 24(3), 235-245. 
Costello, J., Egger, H. \& Angold, A. (2005). 10-Year Research Update Review: The Epidemiology of Child and Adolescent Psychiatric Disorders: Methods and Public Health Burden. Journal of the American Academy of Child and Adolescent Psychiatry, 44(10), 972-986.

Dadds, M., Holland, D., Laurens, K., Mullins, M., Barrett, P. \& Spence, S. (1999). Early Intervention and Prevention of Anxiety Disorders in Children: Results at 2-Year Follow-Up. Journal of Consulting and Clinical Psychology, 67(1), 145-150.

Edwards, S., Rapee, R., Kennedy, S. \& Spence, S. (2010). The Assessment of Anxiety Symptoms in Preschool-Aged Children: The Revised Preschool Anxiety Scale. Journal of Clinical Child \& Adolescent Psychology, 39(3), 400-409.

Epstein, M. (2010). Escala de Evaluación Emocional y de Comportamiento (2da. Edición Español, BERS-2S) [Instrumentos de evaluación]. México: Proed Latinoamérica.

Epstein, M., Harniss, M., Pearson, N. \& Ryser, G. (1999). The Behavioral and Emotional Rating Scale: Test-Retest and Inter-Rater Reliability. Journal of Child and Family Studies, 8(3), 319-327.

Epstein, M. H., \& Sharma, J. (1998). The Behavior and Emotional Rating Scale: A Strength, Based Approach to Assessment. Austin: PRO-ED.

Essau, C., Conradt, J., Sasagawa, S. \& Ollendick, T. (2012). Prevention of Anxiety Symptoms in Children: Results from a Universal School-Based Trial. Behavior Therapy, 43(2), 450-464.

Fisak, B.J., Richard, D., \& Mann, A. (2011). The Prevention of Child and Adolescent Anxiety: A Meta-Analytic Review. Prevention Science, 12, 255-268. https://doi.org/10.1007/s11121-011 $-0210-0$

Figueroa, A., Soutullo, C., Ono, Y. \& Saito, K. (2016). Ansiedad por separación. In Rey, J. (Ed), IACAPAP e-Textbook of Child and Adolescent Mental Health (pp. 1-26). Geneva: International Association for Child and Adolescent Psychiatry and Allied Professions.

Franco, M., Beja, M., Candeias, A. \& Santos, N. (2017). Emotion Understanding, Social Competence and School Achievement in Children from Primary School in Portugal. Frontiers in Psychology, 15(8). https://doi.org/10.3389/fpsyg.2017.01376

Gallegos-Guajardo, J., Ruvalcaba-Romero, N., Garza-Támez, M. \& Villegas-Guinea, D. (2013). Social Validity Evaluation of the FRIENDS for Life Program with Mexican Children. Journal of Education and Training Studies, 1(1), 158-169. 
Gallegos-Guajardo, J., Ruvalcaba-Romero, N., Villegas-Guinea, D. Marques, L. \& Benavides-Torres, R. (2013). Psychometric Properties of the Strengths and Difficulties Questionnaire (SDQ) among Mexican School-Aged Children. Manuscript submitted for publication.

Goodman, R. (2006). The Strengths and Difficulties Questionnaire: A Research Note. Journal of Child Psychology Psychiatry, 38, 581-586. https://doi.org/10.1111/j.1469-7610.1997.tb01545.x

Goodman, R. (2001). Psychometric Properties of the Strenghts and Difficulties Questionnaire. Journal of the American of Child and Adolescent Psychiatry 40(11), 1337- 1345.

Higgins, E., \& O'Sullivan, S. (2015). "What Works": Systematic Review of the "FRIENDS for Life" Programme as a Universal School-Based Intervention Programme for the Prevention of Child and Youth Anxiety. Educational Psychology in Practice, 31(4), 424-438.

Kieling, C., Baker-Henningham, H., Belfer, M., Conti, G., Ertem, I., Omigbodun, O., Rohde, L., Srinath, S., Ulkuer, N. \& Rahman, A. (2011). Child and Adolescent Mental Health Worldwide: Evidence for Action. The Lancet, 378(9801), 1515-1525.

Masten, A. S., Best, K., \& Garmezy, N. (1990). Resilience and Development: Contributions from the Study of Children Who Overcome Adversity. Development and Psychopathology, 2(4), 425-444. https://doi.org/10.1017/S0954579400005812

Masten, A. S. (2014, paperback ed. 2015). Ordinary Magic: Resilience in Development. New York: Guilford Press.

Mathews, B., Koehn, A., Abtahi, M. \& Kerns, K. (2016). Emotional Competence and Anxiety in Childhood and Adolescence: A Meta-Analytic Review. Clinical Child and Family Psychology Review, 19(2), 162-184.

Medina-Mora, M., Borges, G., Benjet, C., Lara, M., Rojas, E., Fleiz, C., Zambrano, J., Villatoro, J., Blanco J. \& Aguilar-Gaxiola, S. (2009). Estudio de los trastornos mentales en México: resultados de la Encuesta Mundial de Salud Mental. In Rodríguez, J., Kohn, R. \& Aguilar-Gaxiola, S. (Eds.). Epidemiología de los trastornos mentales en América Latina y el Caribe (pp. 79-89). Estados Unidos: Organización Panamericana de la Salud.

Merikangas, K., Mehta, R., Molnar, B., Walters, E., Swendsen, J., Aguilar-Gaxiola, S.. \& Kessler, R. (1998). Comorbidity of Substance Use Disorders with Mood and Anxiety Disorders: Results of the International Consortium in Psychiatric Epidemiology. Addictive Behaviors, 23(6), 893-907. 
Ojeda, A., Lima, L. \& González, R. (2013). Papá y mamá: dos maneras de ver la vida... Y una misma educación. Enseñanza e investigación en psicología, 18(1), 51-67.

Oswald, D., Zaidi, H., Cheatham, D. \& Brody, K. (2018). Correlates of Parent Involvement in Students' Learning: Examination of a National Data Set. Journal of Child and Family Studies, 27(1), 316323. https://doi.org/10.1007/s10826-017-0876-4

Pahl, K. \& Barrett, P. (2010). Preventing Anxiety and Promoting Social and Emotional Strength in Preschool Children: A Universal Evaluation of the Fun FRIENDS Program. Advances in School Mental Health Promotion, 3(3), 14-25.

Polanczyk, G., Salum, G., Sugaya, L., Caye, A. \& Rhode, L. (2015). Annual Research Review: A MetaAnalysis of the Worldwide Prevalence of Mental Disorders in Children and Adolescents. The Journal of Child Psychology and Psychiatry, 56(3), 345-365.

Rogers, A. \& Dusmuir, S. (2013). A Controlled Evaluation of the 'FRIENDS for Life' Emotional Resiliency Programme on Overall Anxiety Levels, Anxiety Subtype Levels and School Adjustment. Child and Adolescent Mental Health, 20(1), 13-19. https://doi.org/10.1111/camh.12030

Ruttledge, R., Devitt, E., Greene, G., Mullany, M., Charles, E., Frehill, J., \& Moriarty, M. (2016). A Randomised Controlled Trial of the FRIENDS for Life Emotional Resilience Programme Delivered by Teachers in Irish Primary Schools. Educational and Child Psychology, 33(2), 69-89.

Sharkey, J., Sukkyung You, Morrison, G., \& Griffiths, A. (2009). Behavioral and Emotional Rating Scale-2 Parent Report: Exploring a Spanish version with at-risk Students. Behavioral Disorders, 35(1), 53-65.

Spence, S., Rapee, R., McDonald, C. \& Ingram, M. (2001). The Structure of Anxiety Symptoms Among Preschoolers. Behavior Research and Therapy, 39, 1293-1316.

Stallard, P., Taylor, G., Anderson, R., Daniels, H., Simpson, N., Philips, R. \& Skryabina, E. (2014). The prevention of anxiety in children through School-Based Interventions: Study Protocol for a 24-Month Follow-Up of the PACES Project. Trials, 15(77), 1-6.

Stopa, J., Barrett, P. \& Golingi, F. (2011). The Prevention of Childhood Anxiety in Socioeconomically Disadvantaged Communities: A Universal School-Based Trial. Advances in School Mental Health Promotion, 3(4), 5-24. https://doi.org/10.1080/1754730X.2010.9715688

Tomyn, J., Fuller-Tyszkiewicz, M., Richardson, B. \& Colla, L. (2016). A Comprehensive Evaluation of a Universal School-Based Depression Prevention Program for Adolescents. Journal of Abnormal Child Psychology, 44(8), 1621-1633. 
Towe-Goodman, N., Franz, L., Copeland, W., Angold, A. \& Egger, H. (2014). Perceived Family Impact of Preschool Anxiety Disorders. Journal of the American Academy of Child and Adolescent Psychiatry, 53(4), 437-446.

Watson, L.A., \& Clark, D. (1991). Tripartite Model of Anxiety and Depression: Psychometric Evidence and Taxonomic Implications. Journal of Abnormal Psychology, 100(3), 316-336.

World Health Organization. (2017). Depression and Other Common Mental Disorders: Global Health Estimates. Retrieved from: https://bit.ly/2LDCRS9

Zertuche, C. (2012). Efectividad del programa 'Amistad y Diversión' en el desarrollo de la resiliencia en niños en edad preescolar. Master thesis. Universidad de Monterrey, México. 